\title{
Energy Indicators in the Context of Globalization
}

\author{
Răzvan Cătălin Dobrea ${ }^{1, *}$, Sorin Petrică Angheluță ${ }^{2}$, and Amelia Diaconu ${ }^{3}$ \\ ${ }^{1}$ Bucharest University of Economic Studies, Romania \\ ${ }^{2}$ Bucharest University of Economic Studies, Romania \\ ${ }^{3}$ Bucharest University of Economic Studies, Romania
}

\begin{abstract}
Globalization leads to new challenges. There is a trend of growth of the population. At the same time, production processes are subject to changes. If the new technologies are based on environmental protection, then we can also be considered that the greenhouse gas emissions will be reduced. As energy requirements are rising, it is important to efficient use of natural resources. This, especially, as energy sources differ from one country to another. In this context, dependence on energy imports becomes important. From this point of view, for the countries of the European Union, the article analyzes the evolution of energy efficiency. In recent years, it trying to replace fossil fuels with renewable fuels. Analyzing the share of energy from renewable sources in total electricity allows us to observe the degree of decarbonisation of the European Union economy. The use of energy from renewable sources allows the development of green technologies and contributes to the protection of the environment. Producing of the energy in a region and transporting it to another region creates bridges and contributes to globalization. Thus, in the process of globalization, the role of energy is increasingly important. The article presents a European analysis of gross and net electricity production.
\end{abstract}

\section{Introduction}

One of the current challenges is to use as high share of clean and sustainable energy [1]. However, fossil fuels are used in a high percentage [2]. It is estimated that, in 2060, the share of renewable energy will be around $75 \%$ of total world electricity production [3]. Bear in mind that often the functioning of the electricity production from renewable sources is influenced by weather conditions [4].

Even if we are talking about renewable energy from traditional biomass and hydropower resources or if we are talking about modern renewable energy based on geothermal, wind and solar energy, energy services lead to more flexible production and autonomy of consumption. In addition, the benefits for both individuals and their communities are related to job security and income [5].

\footnotetext{
* Corresponding author: razvan.dobrea@man.ase.ro
} 
In the last decade of the 20th century and the first decade of the 21 st century, although fossil fuel prices were lower than those for renewable energy, energy consumption based on renewable energy increased [6]. Thus, energy services have made it possible to reduce carbon dioxide emissions, as well as to customize energy technologies. In many countries, revenue increases have been observed based on the replacement of fossil fuels with renewable energy. At the same time, this was accompanied by a reduction in carbon dioxide emissions [5].

The implementation of new energy models leads to the emergence of regional electricity markets. One such example is the Iberian Electricity Market (Mibel). Through a common electricity market, both consumers in Spain and Portugal have access to electricity under equivalent conditions [7]. Another example can be given by generating electricity in the Drina Basin. In this case, cross-border collaboration on hydro-electric power has increased, interconnections between countries have increased and energy efficiency measures have been implemented [8].

World population growth, industrialization and economic growth, lead to structural and lifestyle changes in the urban and rural populations [9]. Thus, in addition to increasing energy consumption, consumer areas also change [10].

\section{Methods}

Through this article, an analysis was made of the comparative situation of gross and net electricity production for the year 2008, respectively for the year 2017, in the member countries of the European Union. It also presents the structure of the share of energy resources in the gross electricity production corresponding to 2017 . The energy efficiency indicator is analyzed by monitoring the progress in 2017 compared to 2008 for primary energy consumption, respectively for final energy consumption. In the second part, the evolution of the share of renewable energy in gross final energy consumption for renewable energy sources in transport, electricity, heating and cooling is presented.

\section{Results and Discussion}

The Europe 2020 Strategy has set energy efficiency targets [11]. Thus, by 2020, the EU wants to reduce energy consumption by about $20 \%$. The demand for energy is quite high [12]. Thus, decreasing consumption as well as renewable sources can form the basis of the energy transition [13]. Regarding energy use, energy transitions will have an impact both on the local environment and on the economy [14] as well as on human development [15].

From the comparative situation presented in Table 1, it is noted that in 2017 gross electricity production was raised in: Germany (596.959 GWh), France (541.579,394 GWh), Italy $(276.048,398 \mathrm{GWh})$, Spain $(239.698 \mathrm{GWh})$. Countries where gross electricity production was low in 2017 are: Malta $(1.479,476 \mathrm{GWh})$, Luxembourg $(1.956,871 \mathrm{GWh})$, Lithuania (3.361,1 GWh), Cyprus (4.896,404 GWh), Latvia (7.336,933 GWh). Compared to 2008 , in 2017, the highest increases were recorded in Latvia $(+41,12 \%)$, Portugal (+ $27,71 \%)$, Estonia $(+22,12 \%)$, Sweden $(+10,08 \%)$. At the same time, compared to 2008 , the most significant decreases in gross electricity production in 2017 are recorded in Lithuania $(-75,03 \%)$, Luxembourg $(-41,09 \%)$, Malta $(-36,01 \%)$, Hungary $(-20,25 \%)$. The situation is similar for net electricity production. 
Table 1. Gross and net electricity production - comparative situation, 2008-2017 (GWh)

\begin{tabular}{|l|l|l|l|l|}
\hline \multirow{2}{*}{ Countries } & \multicolumn{3}{|l|}{ Gross electricity production } & \multicolumn{2}{l}{ Net electricity production } \\
\cline { 2 - 5 } & 2008 & 2017 & 2008 & 2017 \\
\hline European Union & $3.130 .104,693$ & $2.998 .424,809$ & $2.973 .045,785$ & $2.852 .579,730$ \\
\hline Austria & $57.926,114$ & $63.109,672$ & $54.680,353$ & $59.893,933$ \\
\hline Belgium & $82.053,000$ & $75.166,100$ & $78.683,000$ & $71.830,400$ \\
\hline Bulgaria & $44.166,000$ & $44.925,176$ & $39.957,000$ & $40.765,454$ \\
\hline Croatia & $12.426,000$ & $11.563,700$ & $11.933,000$ & $11.123,900$ \\
\hline Cyprus & $4.997,637$ & $4.896,404$ & $4.729,637$ & $4.670,319$ \\
\hline Czechia & $73.959,000$ & $77.938,740$ & $68.399,000$ & $71.731,224$ \\
\hline Denmark & $34.319,000$ & $28.198,715$ & $32.555,000$ & $26.813,091$ \\
\hline Estonia & $10.468,000$ & $12.783,685$ & $9.397,000$ & $11.133,000$ \\
\hline Finland & $65.308,000$ & $57.690,000$ & $62.871,000$ & $55.688,000$ \\
\hline France & $554.117,900$ & $541.579,394$ & $529.818,831$ & $518.248,851$ \\
\hline Germany & $591.008,000$ & $596.959,000$ & $555.428,000$ & $566.281,000$ \\
\hline Greece & $62.438,000$ & $53.332,980$ & $58.118,000$ & $48.911,464$ \\
\hline Hungary & $39.643,000$ & $31.616,000$ & $37.026,000$ & $29.503,000$ \\
\hline Ireland & $28.360,025$ & $28.670,582$ & $27.095,993$ & $27.950,280$ \\
\hline Italy & $300.365,000$ & $276.048,398$ & $289.204,127$ & $266.124,512$ \\
\hline Latvia & $5.199,000$ & $7.336,933$ & $4.833,000$ & $6.839,190$ \\
\hline Lithuania & $13.462,000$ & $3.361,100$ & $12.381,000$ & $3.214,500$ \\
\hline Luxembourg & $3.367,896$ & $1.956,871$ & $3.327,771$ & $1.926,542$ \\
\hline Malta & $2.312,000$ & $1.479,476$ & $2.185,000$ & $1.430,156$ \\
\hline Netherlands & $85.495,073$ & $92.218,951$ & $82.276,073$ & $89.217,930$ \\
\hline Poland & $148.564,000$ & $158.553,598$ & $135.157,000$ & $143.854,239$ \\
\hline Portugal & $39.932,048$ & $50.995,738$ & $38.542,000$ & $49.232,995$ \\
\hline Romania & $62.060,000$ & $57.282,522$ & $57.593,000$ & $52.637,838$ \\
\hline Slovakia & $26.210,000$ & $24.646,000$ & $24.014,000$ & $23.079,000$ \\
\hline Slovenia & $15.860,000$ & $15.594,811$ & $14.845,000$ & $14.693,119$ \\
\hline Spain & $275.858,000$ & $239.698,000$ & $265.563,000$ & $230.065,000$ \\
\hline Sweden & $143.566,000$ & $158.035,000$ & $140.150,000$ & $154.529,000$ \\
\hline United Kingdom & $346.664,000$ & $282.787,263$ & $332.283,000$ & $271.191,793$ \\
\hline & & & & \\
\hline
\end{tabular}

Depending on the type of fuel used, the gross electricity production structure for the European Union in 2017 is shown in Figure 1 (\%). It is noted that the most used resources are: combustible fuels $(46,233 \%)$, nuclear fuels and other fuels n.e.c. $(27,672 \%)$, wind $(11,686 \%)$, hydro $(10,846 \%)$. Combustible fuels are most used in: Germany $(348.810$ GWh), Italy (189.673,731 GWh), United Kingdom (161.416,285 GWh), Poland $(140.614,172 \mathrm{GWh})$. Hydro is predominantly used in: Sweden $(65.156 \mathrm{GWh})$, France (54.553,994 GWh), Austria (41.773,288 GWh), Italy (37.535,978 GWh).

Economic development involves increasing consumption, including the consumption of resources needed to produce electricity. This has led to the depletion of fossil fuel resources. So, they raise the requirements for clean energies that use renewable sources. Geothermal energy is an example of a renewable source used more and more often lately. Their advantage is given by their continued availability. Thus, carbon dioxide emissions can be reduced [16, 17]. Countries where geothermal energy is most used are: Italy $(6.201,159 \mathrm{GWh})$, Portugal (216,659 GWh), Germany (163 GWh), France (124,539 GWh).

The use of wind and solar energy and the growth of renewable energy sources with low carbon emissions allow the mitigation of the effects of climate change [18]. Wind is used to 
generate electricity in: Germany (105.693 GWh), Spain (49.115 GWh), United Kingdom (41.005,751 GWh), France (23.032,706 GWh).

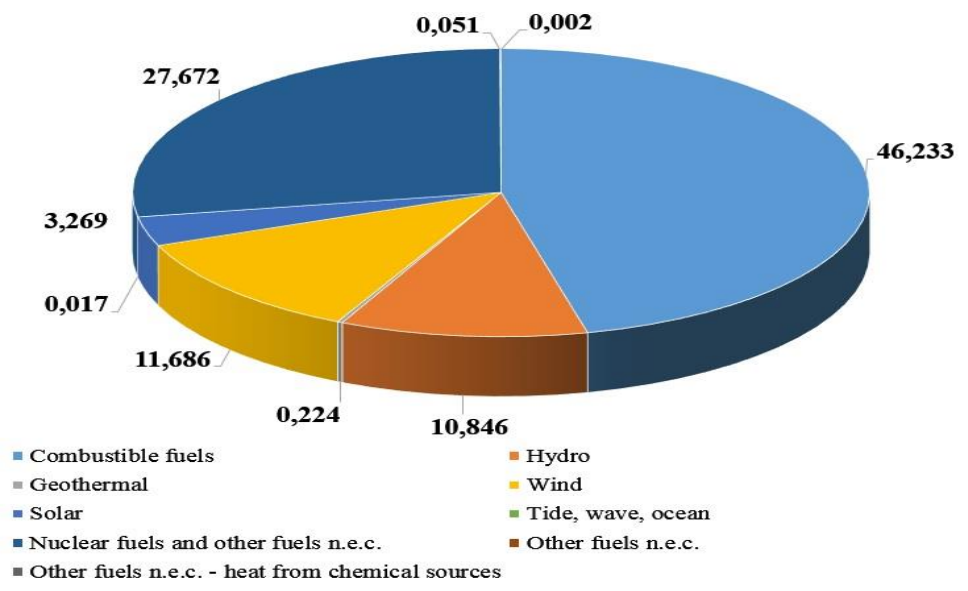

Fig. 1. Share of energy resources in gross electricity production, 2017 (\%)

With regard to solar photovoltaic panels, their cost has decreased in recent years. Under these circumstances, the interest of local communities in energy generation and consumption has also increased. Solar power production is achieved in: Germany (39.401 GWh), Italy (24.377,711 GWh), Spain (14.364 GWh), and with tide, wave, ocean in France $(521,706 \mathrm{GWh})$. Nuclear fuels and other fuels n.e.c. are used to produce electricity in: France $(398.359,129 \mathrm{GWh})$, Germany $(76.324 \mathrm{GWh})$, United Kingdom $(70.336,426 \mathrm{GWh})$, Sweden (65.696 GWh), Spain (58.039 GWh). Using other fuels n.e.c. (not elsewhere classified) is carried out in: Germany $(585 \mathrm{GWh})$, Italy $(517,910 \mathrm{GWh})$, France $(254,693$ GWh), and in Sweden (51 GWh) other fuels n.e.c. - heat from chemical sources are used.

Combating the effects of global warming can also be achieved by using renewable energies. Such a renewable technology is biogas. It can be used both for the production of electricity and for the removal of carbon dioxide [19].

Technology improvement allowed global renewable energy costs to be lower than for fossil fuels [20]. Energy efficiency measures have led to a reduction in the pressure on primary energy supplies. Also, the production of hydropower plants could be improved by better cooperation in the operation of hydropower plants [8]. Thus, for the energy efficiency indicator, the monitoring of the progress achieved in 2017 compared to 2008 for primary energy consumption and final energy consumption respectively is shown in the table below, in million tonnes of oil equivalent (Mtoe).

From the data presented at the level of the European Union, the descending trend is observed. Thus, the most significant decreases for primary energy consumption were recorded in: United Kingdom (-34,98\%), Italy (-27,17\%), Germany (-18,79\%), France ($15,87 \%)$, Spain $(-8,81 \%)$, Greece $(-7,19 \%)$. For final energy consumption, significant decreases were in: Italy $(-19,09 \%)$, United Kingdom (-14,94\%), Spain (-10,50\%), France ($6,92 \%)$, Greece $-4,62 \%)$.

One of the sectors using fossil fuels is the transport sector. A strong impact on the reduction of carbon dioxide emissions may be in electric vehicles and hybrid systems (Razmjooa \& Sumpera, 2019). Analyzing the comparative situation presented in Table 3, it is noted that in 2017 compared to 2004, renewable energy sources in transport increased significantly for: Ireland (7,394\%), France (7,666\%), Portugal (7,51\%), Finland (17,815\%), Sweden $(25,825 \%)$. In 2017 , the highest values were recorded in Sweden $(32,112 \%)$, Finland (18,825\%), Austria (9,74\%), France (9,141\%), Portugal (7,934\%). 
Table 2. Comparative situation primary-final energy consumption (Mtoe)

\begin{tabular}{|c|c|c|c|c|}
\hline \multirow{2}{*}{ Countries } & \multicolumn{2}{|c|}{ Primary energy consumption } & \multicolumn{2}{|c|}{ Final energy consumption } \\
\hline & 2008 & 2017 & 2008 & 2017 \\
\hline European Union & $1.696,86$ & $1.561,59$ & $1.180,27$ & $1.122,77$ \\
\hline Austria & 32,09 & 32,55 & 27,32 & 28,42 \\
\hline Belgium & 51,13 & 49,12 & 37,00 & 36,05 \\
\hline Bulgaria & 19,02 & 18,33 & 9,98 & 9,89 \\
\hline Croatia & 9,20 & 8,33 & 7,40 & 6,92 \\
\hline Cyprus & 2,85 & 2,52 & 1,97 & 1,85 \\
\hline Czechia & 42,51 & 40,36 & 26,09 & 25,49 \\
\hline Denmark & 19,90 & 17,74 & 15,53 & 14,62 \\
\hline Estonia & 5,36 & 5,64 & 3,10 & 2,87 \\
\hline Finland & 34,57 & 31,93 & 25,70 & 25,29 \\
\hline France & 255,39 & 239,52 & 155,87 & 148,95 \\
\hline Germany & 317,10 & 298,31 & 218,05 & 218,71 \\
\hline Greece & 30,31 & 23,12 & 21,37 & 16,75 \\
\hline Hungary & 25,16 & 24,48 & 17,44 & 18,51 \\
\hline Ireland & 15,63 & 14,41 & 13,36 & 11,76 \\
\hline Italy & 176,12 & 148,95 & 134,28 & 115,19 \\
\hline Latvia & 4,58 & 4,47 & 4,15 & 4,01 \\
\hline Lithuania & 8,26 & 6,16 & 5,13 & 5,35 \\
\hline Luxembourg & 4,61 & 4,30 & 4,38 & 4,18 \\
\hline Malta & 0,96 & 0,81 & 0,50 & 0,63 \\
\hline Netherlands & 69,89 & 64,54 & 53,92 & 50,34 \\
\hline Poland & 93,09 & 99,11 & 62,40 & 70,92 \\
\hline Portugal & 23,59 & 22,79 & 18,40 & 16,56 \\
\hline Romania & 37,32 & 32,37 & 24,68 & 23,21 \\
\hline Slovakia & 16,98 & 16,15 & 11,45 & 11,13 \\
\hline Slovenia & 7,49 & 6,64 & 5,27 & 4,86 \\
\hline Spain & 134,44 & 125,63 & 94,83 & 84,33 \\
\hline Sweden & 47,52 & 46,48 & 32,39 & 32,64 \\
\hline United Kingdom & 211,80 & 176,82 & 148,29 & 133,35 \\
\hline
\end{tabular}

Renewable energy sources in electricity increased significantly for: Denmark $(36,602 \%)$, Germany $(25,033 \%)$, Ireland $(24,059 \%)$, Italy $(18,018 \%)$, Portugal $(26,778 \%)$, United Kingdom $(24,58 \%)$. In 2017, the highest values were recorded in: Austria $(72,173 \%)$, Sweden $(65,885 \%)$, Denmark $(60,356 \%)$, Latvia $(54,357 \%)$, Portugal $(54,168 \%)$. Major increases for renewable energy sources in heating and cooling were registered in: Denmark $(25,906 \%)$, Estonia (18,423\%), Malta $(18,798 \%)$, Sweden $(22,437 \%)$. 
Table 3. Comparative situation of share of renewable energy in gross final energy consumption by sector $(\%)$

\begin{tabular}{|c|c|c|c|c|c|c|}
\hline \multirow[t]{2}{*}{ Countries } & \multicolumn{2}{|c|}{$\begin{array}{l}\text { Renewable energy } \\
\text { sources in transport }\end{array}$} & \multicolumn{2}{|c|}{$\begin{array}{lr}\text { Renewable } & \text { energy } \\
\text { sources } & \text { in } \\
\text { electricity } & \\
\end{array}$} & \multicolumn{2}{|c|}{$\begin{array}{l}\text { Renewable energy } \\
\text { sources in heating and } \\
\text { cooling }\end{array}$} \\
\hline & 2004 & 2017 & 2004 & 2017 & 2004 & 2017 \\
\hline European Union & 1,390 & 7,386 & 14,299 & 30,747 & 10,405 & 19,484 \\
\hline Austria & 4,533 & 9,740 & 61,625 & 72,173 & 20,165 & 32,050 \\
\hline Belgium & 0,526 & 6,576 & 1,688 & 17,237 & 2,846 & 8,032 \\
\hline Bulgaria & 0,876 & 7,244 & 9,095 & 19,117 & 14,056 & 29,901 \\
\hline Croatia & 0,993 & 1,181 & 35,026 & 46,415 & 29,439 & 36,546 \\
\hline Cyprus & 0 & 2,571 & 0,011 & 8,905 & 9,264 & 24,491 \\
\hline Czechia & 1,570 & 6,580 & 3,693 & 13,654 & 9,930 & 19,654 \\
\hline Denmark & 0,445 & 6,847 & 23,754 & 60,356 & 20,642 & 46,548 \\
\hline Estonia & 0,181 & 0,405 & 0,470 & 17,027 & 33,222 & 51,645 \\
\hline Finland & 1,010 & 18,825 & 26,711 & 35,221 & 39,504 & 54,849 \\
\hline France & 1,475 & 9,141 & 13,782 & 19,907 & 12,524 & 21,349 \\
\hline Germany & 2,212 & 7,034 & 9,372 & 34,405 & 7,147 & 13,423 \\
\hline Greece & 0,078 & 1,804 & 7,842 & 24,473 & 12,774 & 26,569 \\
\hline Hungary & 0,917 & 6,806 & 2,220 & 7,485 & 6,450 & 19,642 \\
\hline Ireland & 0,040 & 7,434 & 6,031 & 30,09 & 2,873 & 6,863 \\
\hline Italy & 1,213 & 6,484 & 16,086 & 34,104 & 5,713 & 20,083 \\
\hline Latvia & 2,139 & 2,544 & 45,958 & 54,357 & 42,488 & 54,584 \\
\hline Lithuania & 0,410 & 3,689 & 3,587 & 18,254 & 30,446 & 46,499 \\
\hline Luxembourg & 0,126 & 6,435 & 2,765 & 8,054 & 1,829 & 8,112 \\
\hline Malta & 0 & 6,797 & 0 & 6,585 & 1,035 & 19,833 \\
\hline Netherlands & 0,464 & 5,912 & 4,447 & 13,804 & 2,210 & 5,928 \\
\hline Poland & 1,441 & 4,203 & 2,209 & 13,089 & 10,207 & 14,485 \\
\hline Portugal & 0,424 & 7,934 & 27,390 & 54,168 & 32,504 & 34,391 \\
\hline Romania & 1,600 & 6,558 & 24,968 & 41,634 & 17,337 & 26,581 \\
\hline Slovakia & 1,459 & 7,026 & 15,403 & 21,343 & 5,062 & 9,837 \\
\hline Slovenia & 0,850 & 2,738 & 29,271 & 32,427 & 18,361 & 33,245 \\
\hline Spain & 1,034 & 5,917 & 18,981 & 36,339 & 9,497 & 17,523 \\
\hline Sweden & 6,287 & 32,112 & 51,181 & 65,885 & 46,63 & 69,067 \\
\hline United Kingdom & 0,346 & 5,05 & 3,531 & 28,111 & 0,728 & 7,454 \\
\hline
\end{tabular}

\section{Conclusion}

Solutions for managing and storing energy produced by solar photovoltaic panels can reduce dependence on a particular network.

The analysis shows a downward trend in gross and net electricity production. It has also been found that the most used resources are: combustible fuels, nuclear fuels and other fuels n.e.c., wind and hydro. At the same time, the evolution of the share of renewable energy in gross final energy consumption shows a growth trend due to the attention given to renewable energy sources.

The transition to sustainable energy requires tackling those low-carbon energy sources. Measures against environmental damage are therefore needed. In this way, renewable energies can diminish the negative impact of climate change [21].

Worldwide, the rural-urban distribution of the population shows a higher share of the urban area [22]. Thus, the energy supply of local communities becomes an increasingly 
important issue. Another important aspect is the degree to which a community has access to energy systems and at what cost. Limited access and high energy costs affect the education and health of members of a community [20].

\section{References}

1. S. Burlacu, C. Gutu, F. O. Matei, Globalization-pros and cons. Calitatea, 19(S1), 122125 (2018)

2. L. Kriechbaum, G. Scheiber, T. Kienberger, Grid-based multi-energy systemsmodelling, assessment, open source modelling frameworks and challenges. Energy, Sustainability and Society (2018)

3. Y. Nakahara, T. Tabata, T. Ohno, F. Furukawa, K. Inokuchi, K. Katagiri, Y. Hirayama, Discussion on regional revitalization using woody biomass resources as renewable energy. International Journal of Energy and Environmental Engineering (2019)

4. A. Fentis, L. Bahatti, M. Tabaa, M. Mestari, Short-term nonlinear autoregressive photovoltaic power forecasting using statistical learning approaches and in-situ observations. International Journal of Energy and Environmental Engineering (2019)

5. Y. Krozer, Valorisation of energy services: essay on the value addition due to renewable energy (2019)

6. C. V. Rădulescu, R. C. Dobrea, S. Burlacu, The business management of distress situations. In 12th International Management Conference "Management Perspectives in the Digital Era” November 1st-2nd, 2018, Bucharest, Romania (2018b)

7. R. Reis da Silva, M. F. Dias, M. Madaleno, Iberian electricity market spot and futures prices: comovement and lead-lag relationship analysis. International Journal of Sustainable Energy Planning and Management (2019)

8. Y. Almulla, E. Ramos, F. Gardumi, C. Taliotis, A. Lipponen, M. Howells, The role of energy-water nexus to motivate transboundary cooperation: An indicative analysis of the Drina River Basin. International Journal of Sustainable Energy Planning and Management, 18, 03-28 (2018)

9. C. V. Rădulescu, D. A. Bodislav, S. Burlacu, Demographic explosion and IT governance in public institutions. Managerial Challenges of the Contemporary Society. Proceedings, 11(1), 18 (2018a)

10. S. Erker, P. Lichtenwoehrer, F. Zach, G. Stoeglehner, Interdisciplinary decision support model for grid-bound heat supply systems in urban areas. Energy, Sustainability and Society (2019)

11. I. Jianu, I. Dobre, D. A. Bodislav, C. V. Radulescu, S. Burlacu, The implications of institutional specificities on the income inequalities drivers in European Union. Economic Computation and Economic Cybernetics Studies and Research, 53(2), 59-76 (2019)

12. S. Burlacu, A. Profiroiu, P. C. Vasilache, Impact of demography on the public finance of the European Union. Calitatea, 20(S2), 136-138 (2019)

13. R. Hölsgens, S. Lübke, M. Hasselkuß, Social innovations in the German energy transition: an attempt to use the heuristics of the multi-level perspective of transitions to analyze the diffusion process of social Innovations. Energy, Sustainability and Society (2018)

14. F. Ionita, M. Ursacescu, S. Burlacu, Public services as poles of regional competitiveness in sustainable development. Revista de Management Comparat 
International/Review of International Comparative Management, 10(3), 552-565 ( 2009)

15. P. D. Saundry, Review of the United States energy system in transition. Energy, Sustainability and Society (2019)

16. C. Peng, B. Pan, L. Xue, H. Liu, Geophysical survey of geothermal energy potential in the Liaoji Belt, northeastern China. Geothermal Energy (2019)

17. C. Tissen, K. Menberg, P. Bayer, P. Blum, Meeting the demand: geothermal heat supply rates for an urban quarter in Germany. Geothermal Energy (2019)

18. L. C. Hamilton, E. Bell, J. Hartter, J. D. Salerno, A change in the wind? US public views on renewable energy and climate compared. Energy, Sustainability and Society (2018)

19. C. Herbes, S. Chouvellon, J. Lacombe, Towards marketing biomethane in FranceFrench consumers' perception of biomethane. Energy, Sustainability and Society (2018)

20. A. A. Razmjooa, A. Sumpera, Investigating energy sustainability indicators for developing countries. International Journal of Sustainable Energy Planning and Management (2019)

21. F. M. Kouhestani, J. Byrne, D. Johnson, L. Spencer, P. Hazendonk, B. Brown, Evaluating solar energy technical and economic potential on rooftops in an urban setting: the city of Lethbridge, Canada. International Journal of Energy and Environmental Engineering (2019)

22. F. Bran, C. Alpopi, S. Burlacu, Territorial Development-Disparities between the Developed and the least Developed Areas of Romania. LUMEN Proceedings, 6(1), 146-155 (20108)

23. Eurostat, 2019. Available at: https://ec.europa.eu/eurostat/web/main 